\title{
Rancang Bangun Rak Penetas Telur Otomatis Pada Mesin Tetas Bertenaga Hybrid
}

\author{
Ferry Budhi Susetyo ${ }^{1}$, I Wayan Sugita ${ }^{2 *}$, Basori ${ }^{3}$, Muhammad Naufal Rifqi ${ }^{1}$, Rois \\ Wardiana $^{1}$, Joko Prasetyo ${ }^{1}$ \\ ${ }^{1}$ Program Studi Teknik Mesin, Fakultas Teknik, Universitas Negeri Jakarta, 13220 \\ ${ }^{2}$ Program Studi Pendidikan Teknik Mesin, Fakultas Teknik, Universitas Negeri Jakarta, 13220 \\ ${ }^{3}$ Program Studi Teknik Mesin, Fakultas Teknik dan Sains, Universitas Nasional, 12520 \\ *Korespondesi penulis: wayan-sugita@unj.ac.id
}

(Received: 19-08-2020; Revised: 16-10-2020; Accepted: 19-10-2020)

\begin{abstract}
Abstrak. Mesin penetas telur pada awalnya merupakan alat sederhana yang hanya menggunakan lampu untuk menghasilkan panasnya tanpa alat-alat pendukung lainnya yang hanya digunakan oleh para peternak tradisional dengan kapasitas yang kecil, namun seiring dengan perkembangan teknologi mesin ini dikembangkan untuk meningkatkan kemampuan dan kemudahan dalam penetasan telur. Pembuatan rak pemutar telur otomatis pada mesin penetas telur ini dan mempunyai dua sumber energi, yaitu energi listrik PLN dan energi panas matahari dengan menggunakan panel surya. Dalam proses modifikasi mesin penetas telur tenaga hybrid ini memiliki beberapa tahapan yaitu diawali dengan tahap sketsa gambar sederhana rak telur otomatis, gambar kerja, proses pembuatan, modifikasi rangkaian kelistrikannya, dan perhitungan tahanan baterai serta ujicobanya pada solar cell. Dari hasil pengujian mesin penetas telur otomatis tenaga hybrid kami ini yaitu rak bergeser otomatis setiap 6 jam sekali dalam waktu 24 jam non-stop.
\end{abstract}

Kata Kunci: rancang bangun, rak telur, penetas telur, sistem otomatis, tenaga hybrid

\section{PENDAHULUAN}

Seiring dengan pertumbuhan penduduk di Indonesia harus diimbangi juga dengan persediaan yang mencukupi untuk memenuhi ketersediaan pangan, sehingga kebutuhan pangan yang mengandung protein tinggi ini terpenuhi [1, 2]. Produk unggas lebih diminati jika dibandingkan dengan ternak besar, selain itu pangan yang mengandung protein tinggi ada pada unggas [3, 4]. Untuk itu peningkatan produktivitas peternak dapat dilakukan dengan penerapan mesin tetas $[5,6]$. Solusi untuk mengatasinya yaitu dengan meningkatkan kemampuan peran mesin penetas telur konvensional menjadi mesin penetas telur otomatis sehingga membuat proses penetasan telur menjadi praktis, efisien, dan dengan hasil penetasan telur yang lebih baik [7]. Peningkatan kemampuan mesin dapat dilakukan dengan kegiatatan rancang bangun [8-10]. Rancang bangun mesin tetas semi otomatis dengan daya 25 watt telah dikembangkan untuk menghasilkan penetasan 120 sampai dengan 150 butir telur, dimana proses memutar raknya dilakukan secara manual periodik waktu tertentu [11]. Selain itu rancang bangun mesin tetas otomatis berbasis mikrokontroler Atmega8585 juga telah dikembangkan dengan keberhasilan yang baik [12].

Kondisi mesin penetas telur sebelum otomatis yaitu memiliki suhu ruangan $37^{\circ} \mathrm{C}-38^{\circ} \mathrm{C}$, didalamnya dilengkapi 4 buah lampu bohlam dengan daya 20 Watt yang dimana setiap bohlamnya memiliki daya sebesar 5 Watt. Tenaga untuk menyalakan lampu bohlam tersebut bersumber dari listrik PLN. Selain dari listrik PLN, sumber lainnya juga dapat diperoleh dari energi matahari dengan menggunakan panel surya yang disimpan pada baterai, untuk menggantikan sementara jika sumber dari listrik PLN sedang bermasalah [1]. 
Terdapat 5 faktor yang harus diperhatikan pada Inkubator mesin tetas yaitu temperatur, kelembapan, sirkulasi udara (ventilasi), pemutaran rak telur, dan kebersihan [7, 13, 14]. Pemutaran rak telur mempunyai tujuan agar panas dapat diberikan secara merata pada permukaan telur, selain untuk mengantisipasi agar embrio dalam telur tidak menempel di salah satu sisi kerabang telur. Dalam penelitian ini kami menggunakan sistem rak telur yang bergeser kanan dan kiri secara otomatis yang berfungsi memutar telur agar hangat nya merata.

\section{METODOLOGI}

Rak telur otomatis pada mesin penetas telur tenaga hybrid dirancang menggunakan sistem rak telur yang bergeser kanan dan kiri secara otomatis yang berfungsi memutar telur agar hangatnya merata. Proses rancang bangun rak telur otomatis dilaksanakan pada bulan November sampai Desember 2019. Lokasi pembuatan rancang bangun rak telur otomatis ini bertempat di laboratorium Teknik Mesin FT Universitas Negeri Jakarta. Lebih jelas mengenai alur proses penelitian dapat terlihat pada bagan alur sebagai berikut.

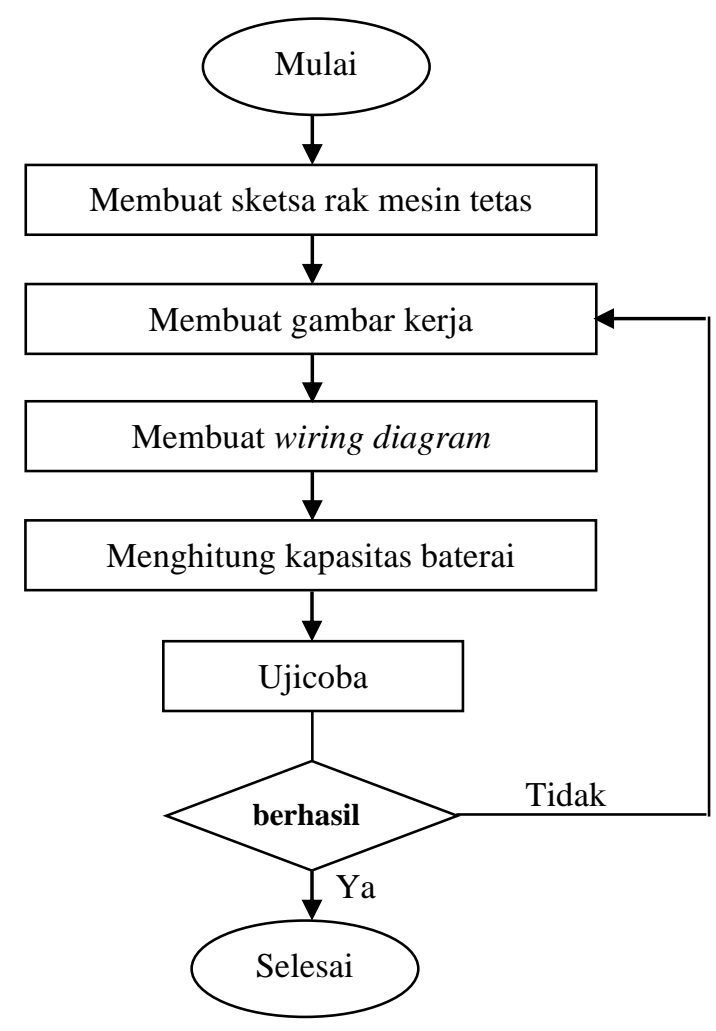

GAMBAR 1. Bagan alur penelitian.

Proses dimulai dengan pembuatan sketsa gambar. Sketsa adalah bentuk visualisasi pemikiran seseorang yang dibuat secara spontan berupa gambar kasar sebagai gambaran awal yang biasanya tidak dimaksudkan untuk dijadikan hasil akhir sebuah karya, sketsa nantinya akan dibuat sebagai gambar kerja atau pengembangan sebuah gagasan. Setelah selesai pembuatan sketsa rak telur otomatis lalu dilanjutkan dengan pembuatan gambar kerja. Pembuatan gambar kerja adalah proses dimana setelah sketsa selesai dan perencanaan ukuran telah dilakukan. Pada pembuatan gambar kerja drafter harus memperhatikan berbagai hal diantaranya adalah bahan yang akan digunakan, proses produksi, dan biaya produksi. Gambar kerja adalah media penyampaian informasi antara drafter dan orang yang memproduksi, maka dari itu gambar kerja harus terstandarisasi serta mengikuti aturan-aturan gambar teknik supaya penyampaian informasi dapat 
berjalan dengan baik. Setelah selesai pembuatan gambar kerja, kemudian dilanjutkan pembuatan gambar wiring kelistrikan. Pada gambar wiring ini akan ditentukan komponen-komponen apa saja yang diperlukan agar rak telur dapat bergerak secara otomatis. Selain itu wiring diberikan secara lengkap mulai dari sumber energi hingga motor penggerak rak dan lampu pemanas.

Setelah selesai menggambar wiring kelistrikan, kemudian dilanjutkan dengan proses perhitungan baterai untuk kebutuhan solar cell. Perhitungan penggunaan aki ini bertujuan untuk mengetahui seberapa lama aki dapat mengoperasikan mesin penetas telur. Adapun perhitungan daya listrik menggunakan persamaan (1).

$$
\mathrm{P}=\mathrm{V} \times \mathrm{I}
$$

Jenis baterai atau aki yang dipakai VRLA (Valve regulated lead acid) aki ini cocok digunakan pada mesin tetas karena bersifat tertutup (sealed), karena tertutup, maka uap yang keluar dari aki sangatlah sedikit (terjadi rekombinasi) sehingga tidak perlu menambah cairan selama masa penggunaan aki, aki ini mempunyai spesifikasi sebagai berikut:

1. Lithium

2. Nominal voltage $12 \mathrm{~V}$

3. Rated capacity $100 \mathrm{AH}$

4. Dimension $\mathrm{P} \times \mathrm{L} \times \mathrm{T}(350 \times 179 \times 183 \mathrm{~mm})$

5. weight $19.5 \mathrm{~kg}$

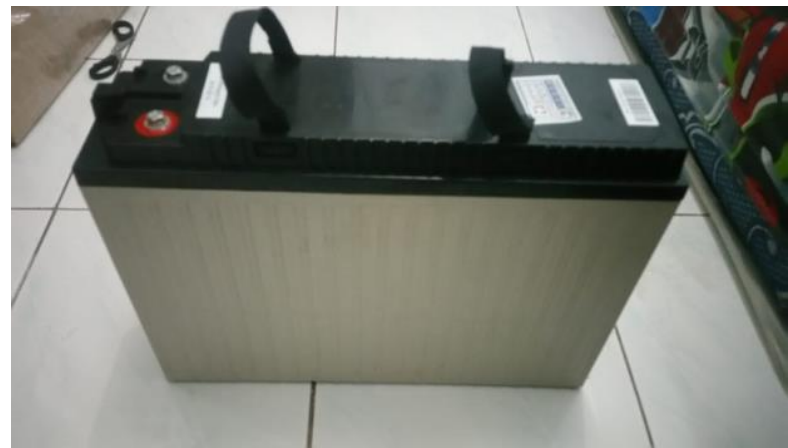

GAMBAR 2. Aki untuk proses penetasan dengan tegangan 12V dan kapasitas 100AH.

Berdasarkan gambar 2 dapat terlihat akumulator atau yang familiar disebut aki pada mesin tetas bertenaga hybrid ini digunakan sebagai media penyimpanan energi listrik yang dihasilkan oleh sel surya, aki bersifat portable dan dapat menyimpan energi listrik melalui proses kimia sehingga energi listrik dapat digunakan di lain waktu. Pada saat ini pengunaan aki sangatlah penting karena sifatnya yang memiliki mobilitas sangat tinggi sehingga sangat dibutuhkan, aki terdapat berbagai jenis dan kapasitas yang begitu beragam, pada mesin tetas bertenaga hybrid ini digunakan aki $12 \mathrm{~V}$ dengan kapasitas 100 AH. Langkah terakhir dari penelitian ini yaitu proses uji coba mesin penetasan telur. Proses pengujian menggunakan energi dari Aki (sumber pengisian dengan solar cell) dan PLN.

\section{HASIL DAN PEMBAHASAN}

\section{Sketsa Gambar Rak Telur Otomatis}

Gambar sketsa dini dibuat untuk mempermudah ketika akan membuat gambar kerja. Gambar sketsa dibuat secara freehand, artinya dibuat tanpa bantuan alat bantu seperti penggaris. Gambar sketsa untuk rak penetas telur dibuat dengan dimensi $44 \times 54 \times 4 \mathrm{~cm}$. Lebih lengkap dapat dilihat pada gambar 3. 
Dari gambar sketsa di atas dapat terlihat gambaran sederhana mengenai rak mesin tetas yang dibuat serta frame yang nantinya akan dibuat gambar kerja. Jika dibandingkan dengan penelitian terdahulu, maka ada sedikit perubahan pada gambar sketsa yang dibuat. Karena rak penetas telur di desain untuk bergerak secara otomatis guna membalik telur yang sedang ditetaskan sehingga ditambahkan frame.

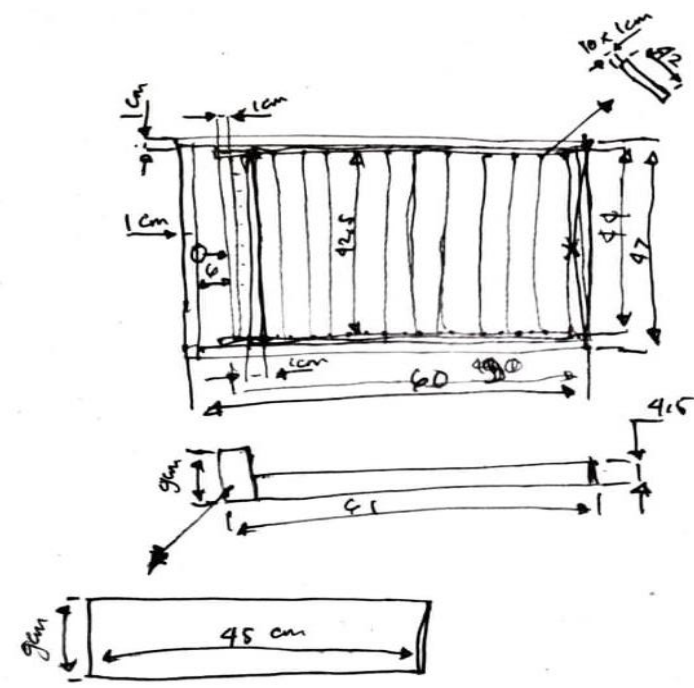

GAMBAR 3. Sketsa rak telur otomatis.

\section{Pembuatan Gambar Kerja}

Setelah selesai pembuatan gambar sketsa kemudian dilanjutkan dengan pembuatan gambar kerja. Gambar kerja yang dibuat dapat terlihat pada gambar 4.

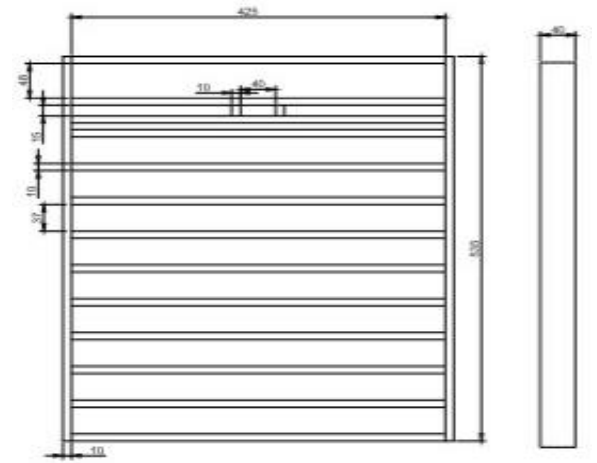

(a)

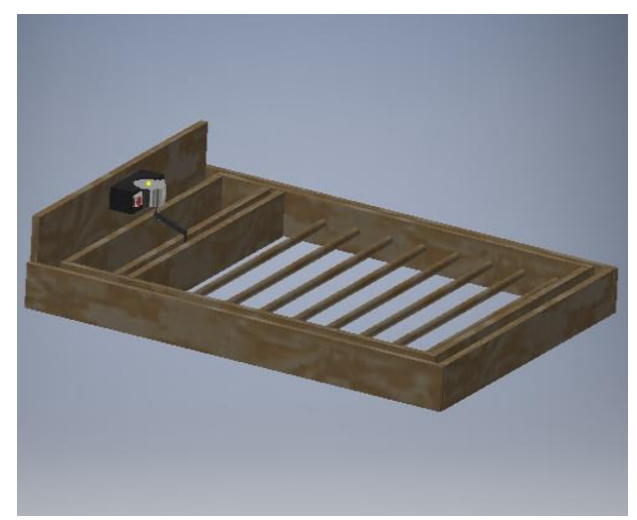

(c)
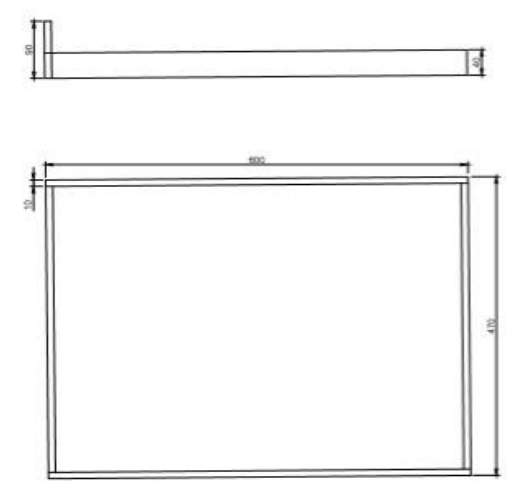

(b)

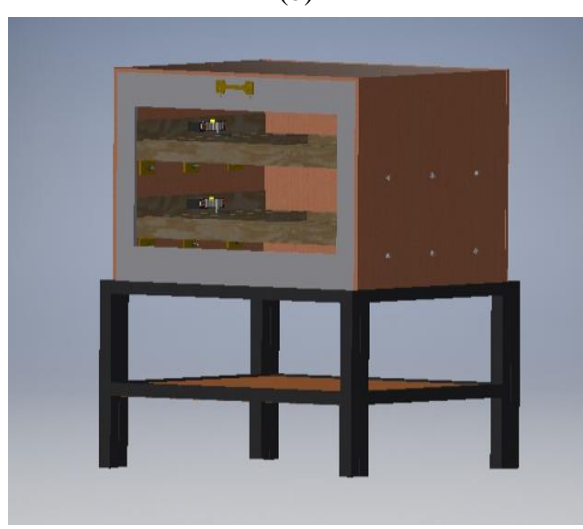

(d)

GAMBAR 4. Perangkat dari mesin tetas telur (a) Rak Telur Otomatis, (b) Tempat Bergerak Rak Telur, (c) 3D Rak Telur Otomatis, dan (d) 3D Assembly Mesin Tetas 
Pada gambar 4 (a) merupakan tahapan terbentuknya rak tempat telur. Terlihat perubahan dari gambar sketsa rak telur sebesar $44 \times 54 \times 4 \mathrm{~cm}$ menjadi $425 \times 535 \times 40 \mathrm{~mm}$. Pada rak ini akan diletakkan telur-telur yang nanti akan di tetaskan dalam mesin penetas. Pada gambar 4 (b) merupakan frame dari rak tempat telur diletakkan. Fungsi dari frame ini nantinya akan menjadi pegangan rak telur untuk bergerak membalikkan telur secara otomatis. Pada gambar 4 (c) dapat terlihat visualisasi dari gambar 3D rak telur otomatis, dimana terlihat juga motor pengerak yang berfungsi untuk menggerakkkan rak telur agar telur-telur dapat berputar atau membalik secara ortomatis. Terakhir pada gambar 4 (d) dapat terlihat mesin tetas secara keseluruahan dalam bentuk 3D. Terlihat ada dua buah rak otomatis secara bertingkat di dalam mesin tetas tersebut.

\section{Pembuatan Gambar Wiring Kelistrikan}

Berdasarkan gambar 5 dapat terlihat ada dua sumber energi yang bisa digunakan untuk proses penetasan yaitu solar cell no (5) dan PLN no (4). Sumber energi ini bisa digunakan secara terpisah, artinya tidak bisa digunakan secara bersamaaan. Ketika menggunakan sumber dari PLN maka MCB no (1) harus dalam posisi on, namus pastikan MCB no (2) dalam posisi off. Sebaliknya demikian, jika ingin menggunakan sumber energi dari baterai (hasil pengisian dari solar cell) maka MCB no (2) harus dalam posisi on dan MCB no 1 harus dalam posisi off.

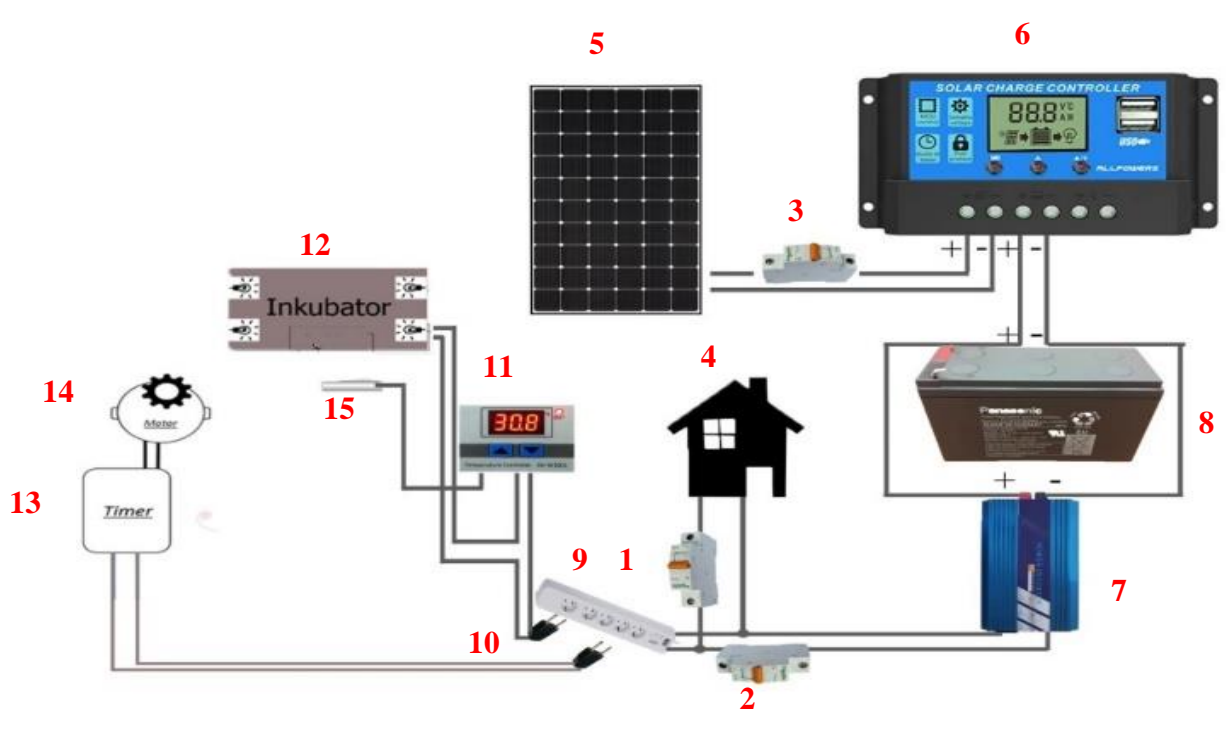

GAMBAR 5. Wiring kelistrikan.

Ketika ingin mengisi baterai dengan solar cell pastikan MCB no (3) dalam posisi on, serta terhubung dengan solar cell charge control no (5) dimana fungsinya adalah untuk mengatur kelistrikan pada solar cell agar tetap konstan. Alat no (7) adalah inverter yang berfungsi untuk pengubah arus listrik searah (DC) menjadi arus bolak balik (AC). Ketika steker no (10) di hubungkan dengan stop kontak no (9), maka proses penetasan dapat berjalan. Kemudian no 11 adalah adalah termokontrol untuk mengatur suhu, dan no (15) adalah termokopel sebagai sensor suhu. Inkubator penetasan dilengkapi dengan empat buah lampu pijar dengan daya 5 Watt.

Untuk proses penetasan dengan otomatis, artinya telur dibalik secara otomatis maka secara periodik dengan mengatur timer no (13) akan otomatis menggerakkan motor no (14) sesuai dengan waktu yang ditetapkan. Sehingga peternak, atau pengguna mesin tetas tidak perlu membalik telur secara periodik.

\section{Perhitungan Baterai untuk Kebutuhan Sollar Cell}

Mesin tetas telur menggunakan aki bertegangan 12 volt dan memiliki kapasitas $100 \mathrm{AH}$ digunakan untuk menghidupkan 4 lampu yang membutuhkan daya masing-masing 
sebesar 5 Watt, termostat sebesar 3 Watt, 2 buah motor listrik masing-masing sebesar 4 watt, dan timer motor sebesar 2 watt. Seberapa lama aki dapat mengoperasikan mesin penetas telur, waktu yang dibutuhkan untuk mengisi kembali aki tersebut menggunakan kuat arus pengisian sebesar 5.47 A (efisiensi aki 20\%) dan berapa besar beban yang digunakan mesin tetas selama 1 periode penetasan.

Dengan memasukkan ke dalam rumus (1) maka dihasilkan arus sebesar $2.75 \mathrm{~A}$. Kemudian dengan menghitung daya tahan baterai (100/2.75 - diefisiensi baterai 20\%) maka didapatkan hasil secara teori aki dapat mengoperasikan mesin tetas selama 29.1 Jam.

Untuk menghitung waktu pengisian baterai maka $(t=(100 / 5.47)+20 \% \times(100 / 5.47))$ sehingga didapatkan hasil watu pengisian baterai selama $21.9 \mathrm{Jam}$.

Kemudian untuk mengetahui jumlah energi listrik yang digunakan selama 1 periode penetasan (22 hari) adalah sebagai berikut:

$20 \times 8=160$ watt (asumsi: daya total lampu, 1 periode digunakan selama 8 jam)

$3 \times 24=72$ watt (asumsi: daya thermostat, 1 periode digunakan selama 24 jam)

$2 \times 24=48$ watt (asumsi: daya timer, 1 periode digunakan selama 24 jam)

$8 \times 0.66=5.28$ watt (asumsi: daya motor listrik, 1 periode digunakan selama 0.66 jam)

Total (lampu+thermostat+timer+motor listrik) $=160+72+48+5,28=285,2$ watt

Selama 1 periode $=285.2 \times 22$ hari $=6276$ watt $=6.276 \mathrm{KW}$.

Pada ujicoba mesin tetas dilakukan dengan dua tahap, yaitu ujicoba dengan menggunakan sumber energi dari PLN kemudian pada tahap dua dilakukan ujicoba dengan menggunakan sumber energi solar cell (aki). Pada ujicoba baik tahap pertama maupun tahap kedua timer motor untuk menggerakkan rak telur diatur untuk bergerak periodik setiap 6 jam.

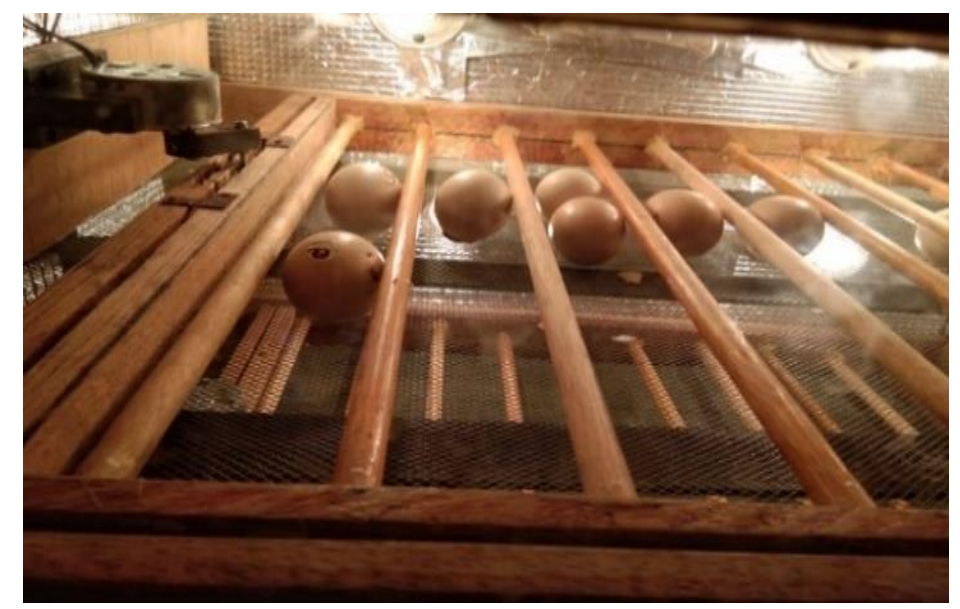

GAMBAR 6. Proses ujicoba rak otomatis.

Gambar 6 merupakan proses ujicoba rak telur otomatis. Dari hasil uji coba baik dengan menggunkan sumber energi dari PLN maupun solar cell (aki) dapat diketahui bahwa rak telur dapat begerak secara periodik setiap 6 jam.

\section{KESIMPULAN}

Berdasarkan hasil perancanaan yang telah dilakukan pada mesin penetas telur otomatis bertenaga hybrid, maka dapat disimpulkan sebagai berikut: Mesin tetas bersifat otomatis pada saat pembalikan telur dan menggunakan sumber energi hybrid yaitu dari listrik PLN dan sel surya. Dengan menggunakan motor penggerak AC didalamnya, rak bergeser setiap 6 jam sekali dalam waktu 24 jam non-stop yang diatur dalam timer. Adapun 
dimensi dari rak mesin tetas yang dirancang maupun dibuat adalah $425 \times 535 \times 40 \mathrm{~mm}$. Dari hasil perhitungan, lama tahan aki yang digunakan untuk mengoperasikan apabila terjadi gangguan jaringan PLN yaitu selama 29.1 jam, sedangkan waktu yang dibutuhkan untuk mengisi kapasitas aki sampai full yaitu selama 21.9 jam. Secara umum dapat diketahui bahwa dari hasil ujicoba rak telur otomatis dapat berfungsi sesuai yang diinginkan.

\section{DAFTAR PUSTAKA}

[1] I. W. Sugita, F. Firmansah, R. Sobirin, and M. R. Ardianto, "Rancang Bangun Mesin Penetas Telur Tenaga Hybrid," J. Konversi Energi dan Manufaktur, vol. 6, no. 1, pp. 30-36, 2019.

[2] R. Fitrah et al., "Pengaruh Temperatur Lama Penimpanan Telur Puyuh Tetas Terhadap Daya Tetas, Fertilitas, Bobot Susut Telur Dan Bobot Tetas Telur Puyuh," J. Peternak. Nusant., vol. 4, no. 1, pp. 25-32, 2018.

[3] N. Meliyati, K. Nova, and D. Septinova, "Pengaruh Umur Telur Tetas Itik Mojosari dengan Penetasan Kombinasi terhadap Fertilitas dan Daya Tetas," J. Ilm. Peternak. Terpadu, vol. 1, no. 1, pp. 472-473, 2012.

[4] Noferdiman, Fatati, and H. Handoko, "Penerapan Teknologi Pakan Lokal Bermutu Dan Pembibitan Ayam Kampung Menuju Kawasan Village Poultry Farming (VPF) Di Desa Kasang Lopak Alai Kabupaten Muaro Jambi,” J. Pengabdi. Pada Masy., vol. 29, no. 3, pp. 60-70, 2014.

[5] R. P. Dewi and W. Arnandi, "Peningkatan Produktivitas Peternak Itik Melalui Penerapan Mesin Penetas Telur," J. Pengabdi. Dan Pemberdaya. Masy., vol. 3, no. 2, pp. 193-196, 2019.

[6] F. Andria, E. M. Effendi, and A. Maesya, "Otomatisasi Mesin Tetas Telur Puyuh Untuk Optimasi Pembibitan, Peningkatan Produksi Dan Pemasaran Bagi Peternak Puyuh," Qardhul Hasan Media Pengabdi. Kpd. Masy., vol. 3, no. 2, p. 107, 2017.

[7] I. Nurhadi and E. Puspita, "Rancang Bangun Mesin Penetas Telur Otomatis Berbasis Mikrokontroler ATMega8 Menggunakan Sensor SHT 11," Students' Creat. Eepis Final Proj. Compet., pp. 1-8, 2009.

[8] A. Muliawan, F. Amalinda, and I. Prasetio, "Rancang Bangun Pengendali Pompa Miniatur Berbasis Mikrokontroler Arduino Bluetooth 4Ch," J. Ilm. GIGA, vol. 21, no. 2, pp. 80-86, 2018.

[9] V. W. Gandoria, V. V. R. Repi, and A. Wibowo, "Rancang Bangun Pengamat Parameter Cuaca Menggunakan Komunikasi Nir Kabel," J. Ilm. GIGA, vol. 22, no. 1, pp. 14-21, 2019.

[10] A. Supriyadi, V. Vekky, R. Repi, and F. Hidayanti, "Rancang Bangun Sistem Pencampuran Warna Tekstil Otomatis dengan Parameter Volume Fluida pewarna," J. Ilm. GIGA, vol. 21, no. 2, pp. 58-68, 2018.

[11] R. Ahaya and S. Akuba, "Rancang Bangun Alat Penetas Telur Semi Otomatis," $J$. Teknol. Pertan. Gorontalo, vol. 3, no. 1, pp. 44-50, 2018.

[12] R. H. Rahim, A. M. Rumagit, and A. S. M. Lumenta, "Rancang Bangun Alat Penetas Telur Otomatis Berbasis Mikrokontroler ATMega8535," J. Tek. Elektro dan Komput., vol. 4, no. 1, pp. 1-7, 2015.

[13] R. Hartono, M. Fathuddin, and A. Izzuddin, "Perancangan dan Pembuatan Alat Penetas Telur Otomatis Berbasis Arduino," ENERGY, vol. 7, no. 1, pp. 30-37, 2017.

[14] E. Fadhila and H. H. Rachmat, "Pengendalian Suhu Berbasis Mikrokontroler Pada Ruang Penetas Telur," J. Reka Elkomika, vol. 2, no. 4, pp. 275-284, 2014. 